Brit. J. vener. Dis. (1965), 41, 155.

\title{
YAWS SURVEY-JAMAICA，1963*
}

\author{
BY \\ G. H. K. GENTLE† \\ Plymouth, Montserrat, West Indies
}

\section{The Country}

Geography. - The island of Jamaica is situated in the Caribbean sea between $17^{\circ} 43^{\prime}$ and $18^{\circ} 32^{\prime} \mathrm{N}$. lat., and $76^{\circ} 11^{\prime}$ and $78^{\circ} 21^{\prime} \mathrm{W}$. long., 100 miles west of Haiti and 90 miles south of Cuba.

The greatest length is 146 miles and greatest width 51 miles, with a total area of 4,500 square miles. The island is divided into thirteen parishes. The surface of the island is extremely mountainous with numerous ridges and spurs extending from east to west. The highest, known as Blue Mountain Peak, attains an elevation of 7,500 feet.

A great diversity of climate exists, from the tropical temperature of $80^{\circ}-86^{\circ}$ along the sea coast to between $40^{\circ}$ and $50^{\circ}$ at the highest elevations. The mean annual rainfall varies from 62.55 in. in the parish of St Ann to 140.46 in. in the parish of Portland. The 25-year mean of the thirteen parishes is 76.64 in. Jamaica abounds with rivers and springs, with most of the former running in a northerly or southerly direction.

The wild life of Jamaica is made up mainly of birds and insects. The agouti is the only indigenous wild animal, and he shares his domain with the feral hog. The mongoose is an immigrant and at one time the crocodiles of the southern rivers were very numerous.

History.-For practical purposes, Jamaica's history begins in 1494 when Columbus landed there. During the next century and a half, the Spaniards annihilated the Arawaks, and imported African slaves and cattle. At the time of the island's capture by the British in 1655 , there were only 1,500 inhabitants, including slaves. The Spaniards released the slaves who fled to the mountains and became known

* Invited article received for publication March 31, 1965.

+ Medical Adviser, WHO/Pan-American Health Organization P.O. Box 724, Georgetown, British Guiana. as the Maroons. For the next 80 years, a guerilla warfare was waged against the British settlers. Up to the period of the emancipation, there was a large scale slavery trade with the West Coast of Africa to obtain a labour force to manage the valuable sugar estates.

After the emancipation in 1838, Jamaica became a land of people free to work for whom they chose. There followed a massive exodus of liberated persons from the estates, and to replace them, labourers were brought in from India. Later in the 19th century Chinese and Lebanese came in mainly as merchants. By the second decade of the 20th century, Jamaica's racial inheritance was completed from African, European, and Asian stock. Table I shows the population growth over 30 years, by age group:

TABLE I

POPULATION 1943-65

\begin{tabular}{l|c|c|c|c}
\hline \multirow{2}{*}{ Total Population $\quad}$. & Census, 1943 & Census, 1960 & $\begin{array}{c}\text { Estimated } \\
1965\end{array}$ \\
\cline { 2 - 5 } & & $1,237,063$ & $1,613,148$ & $1,757,200$ \\
\hline \multirow{2}{*}{$\begin{array}{c}\text { Age Group } \\
\text { (yrs) }\end{array}$} & $\begin{array}{c}0-14 \\
15-49\end{array}$ & & 674,000 & 793,600 \\
& 50 and & & 724,300 & 703,200 \\
& Over & & 222,600 & 260,400 \\
\hline
\end{tabular}

\section{A History of Yaws in Jamaica}

Yaws was first identified in the West Indies early in the 17th century. Its introduction into Jamaica is stated to have followed the importation of African slaves during the 16th century. Several physicians wrote about the disease in Jamaica, but one in particular recorded the following observations concerning the methods by which yaws may be contracted:

(a) By sleeping in the same bed and the "ichor" from the yaws getting in wounds or scratches of the infected. 
(b) By handling the infected and allowing the virus to touch scratches or excoriations.

(c) By a sore considered not yaws, eventually turning out to be yaws. In the meantime the patient may have washed his foot in the same bowl or basin as other persons, and thus passed on the disease.

(d) By small flies gorging themselves with the "ichor" of the infected alighting on the ulcers, etc., of those who never had the disease.

It would appear that up to the time of the emancipation, the disease was kept under control by isolation of cases in "yaws huts". After the emancipation in 1834 , a large number of liberated persons dispersed throughout the island, and it is presumed that the disease flourished among them. Freedom from slavery, the lack of money to pay for medical attention, and their belief in "obeah" medicine, kept them from seeing regular physicians.

In 1852, a report by the Central Board of Health stated that "Yaws are distinctly an African disease. It is singular that previous to the emancipation, every estate had its 'yaws hut', which was filled, ... In towns it is rarely or never seen."

In the year 1854, labourers were imported into the island from India. The Government was responsible for their medical treatment, and the prevalence of yaws among this group which presumably had become infected after arrival, made the Government realize that this disease had become a major public health problem. In spite of organized treatment following the introduction of Salvarsan in 1911, the disease appeared to be just as prevalent in 1930 as before.

Since 1920, the Government had expended from $£ 2,000-£ 8,000$ per annum for the treatment of this disease. The methods used benefited the patient, but failed to control the disease. In view of this, a Commission was organized to study the public health and epidemiological aspects of yaws.

\section{The Jamaica Yaws Commission}

In 1932, the Yaws Commission was organized upon the invitation of the Government to the Rockefeller Foundation to cooperate in a study of this disease. Much valuable irformation was published on the epidemiological features, treatment, and control of yaws. Among the salient epidemiological features brought to light, was that concerning its transmission by the Hippelates fly. It is recorded that these flies were liberal feeders on yaws ulcers, and it was believed that they played an important part in the transmission of infection. Undoubtedly, the most important single factor in the spread of infection was intimate contact between the infected and noninfected.

During 1932 field work was confined to districts in the parish of St Thomas, where special methods were tried for the discovery of cases and treatment of the infected. In 1933 the activities of the Commission developed along three principal lines:

(a) The Research Unit worked on the following problems:

(1) A study of the central nervous sytem in yaws.

(2) Biopsy studies of representative yaws lesions.

(3) Cardiovascular involvement.

(4) Transmission.

(5) Effects of drugs on the disease.

(6) Follow-up of old treated cases.

(7) Immunity reactions.

(8) Comparative studies of yaws and syphilis.

(b) Two Treatment Units were organized with a medical officer in charge of a survey team, and a treatment team. The former consisted of two speciallytrained sanitary inspectors. An assistant, two sanitary inspectors, and a clerk were assigned to the latter.

The Yaws Commission found that bismuth injections taken regularly gave just as good results as Salvarsan. Follow-up of cases treated with each of these drugs over a period of 3 years showed that the number of cures were the same. The action of bismuth was slower, but lasted longer. Salvarsan produced quicker healing, but like bismuth needed at least six regular treatments to produce a permanent cure.

(c) The Central Laboratory served as an adjunct to field work, and provided opportunity for laboratory investigations.

It is understood that the cooperation of the Department of Education was solicited, and questionnaires were sent out to all schools in the island, to determine the incidence of yaws among school children. The treatment of yaws in Jamaica is covered by Law 23 of 1910, which imposes on householders and school teachers the duty of reporting cases of the disease to the District Medical Officer (DMO) in the district where the cases existed. Treatment was to be arranged by the DMO, who also employed district constables to find cases, report them, and bring them in for treatment.

Table II (opposite) gives data relating to yaws for the period of the Commission's work from 1932-36 in certain areas in six eastern parishes. Figs 1 and 2 (opposite) show the areas surveyed and the percentage distribution of yaws recorded by the Commission. 


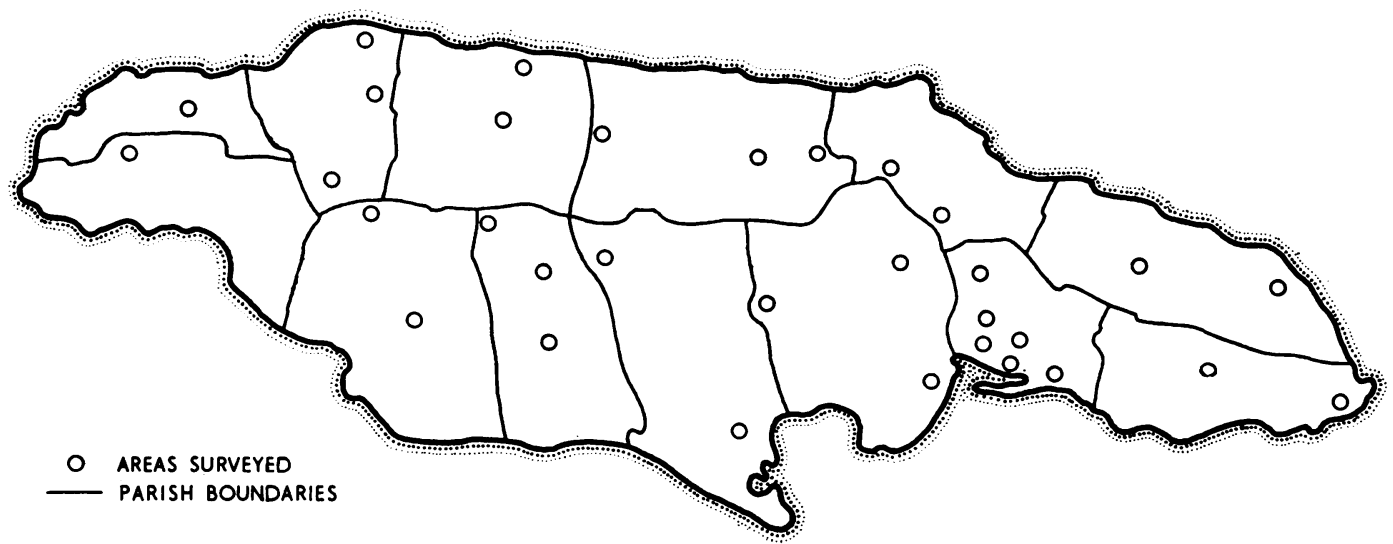

FIG. 1.-Areas surveyed in Jamaica.

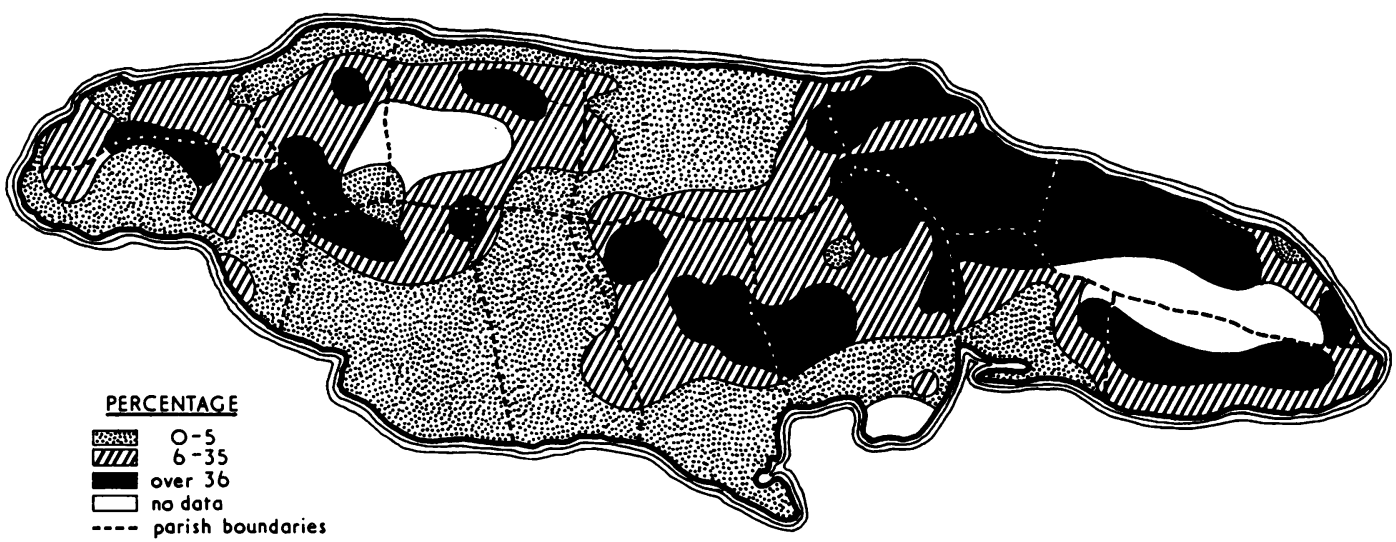

FIG. 2.-Distribution of yaws in Jamaica.

TABLE II

JAMAICA YAWS COMMISSION

POPULATION IN AREAS WHERE YAWS CONTROL WAS INSTITUTED

\begin{tabular}{|c|c|c|c|c|}
\hline \multicolumn{2}{|l|}{ Year } & $\begin{array}{c}\text { No. of } \\
\text { New Areas }\end{array}$ & $\begin{array}{c}\text { Total } \\
\text { Population }\end{array}$ & $\begin{array}{c}\text { No. of Persons } \\
\text { Treated for } \\
\text { Yaws }\end{array}$ \\
\hline $\begin{array}{l}1932 \ldots \\
1933 \ldots \\
1934 \ldots \\
1935 \ldots \\
1936 \ldots\end{array}$ & $\begin{array}{l}\cdots \\
\cdots \\
\cdots \\
\cdots\end{array}$ & $\begin{array}{l}1 \\
5 \\
7 \\
8 \\
8\end{array}$ & $\begin{array}{r}2,300 \\
12,605 \\
22,578 \\
35,323 \\
38,487\end{array}$ & $\begin{array}{r}570 \\
2,616 \\
4,844 \\
8,337 \\
7,923\end{array}$ \\
\hline Total & . & 29 & $111,293^{*}$ & 23,310 \\
\hline
\end{tabular}

* About 50 per cent. of the entire number had had yaws at some time. The following parishes were covered: St Thomas, Portland, St Mary, St Catherine, St Andrew, and Clarendon.

\section{Period of Return to Local Control}

Following the termination of the Commission's work in 1937, the Island Medical Department resumed full control.
Two additional units were established to supplement those employed with the Commission. The scope of activities of these units was widened, and they functioned as health units, to provide immunizations against smallpox and typhoid, to carry out de-worming, and to set up rural latrine sanitation. Each unit was mobile, and comprised a medical officer, a public health supervisor, a public health nurse, a dispenser, and a team of inspectors. The units covered districts where their services were in greatest demand. This system operated for 4 years from 1937-42.

In the year 1943, Colonial Development and Welfare Schemes came into operation. Funds were provided by the United Kingdom Government to assist the Caribbean Territories with their public health problems, including the control of venereal diseases and yaws. The four units in Jamaica were reconstituted to handle malaria, health education, and rural health demonstrations in addition to yaws. 
The scheme also provided for a yaws control officer.

In 1955, following a request by the Government, the WHO/PAHO VD/Yaws Consultant prepared a plan for "The Eradication of Yaws and Control of Venereal Diseases in Jamaica". The plan was not adopted, because priority was given to the Malaria Eradication Programme.

Apparently, the intensive work against yaws conducted by the health units in the late '40s and early ' 50 s was successful in bringing about a marked control of the disease. In 1952 the number of health units was reduced to two, and these were eventually withdrawn from service in 1957 as a marked reduction in cases had occurred. In 1950, the VD specialist was appointed Yaws Control Officer for the island. Responsibility for case finding and treatment was vested in the Parish Medical Services and all cases were referred to the District Medical Officer for treatment. In spite of these measures, yaws has continued to flourish to a greater or lesser degree in various parts of the country.

On November 30,1961, the notification of yaws was made compulsory. Fig. 3 shows the trend of cases for the period 1949-62. The sharp rise in 1953 is attributed to the very intensive field work conducted by the health units.

\section{The Survey}

This was developed by the VD Division to determine the prevailing characteristics and extent of the problem in the island.

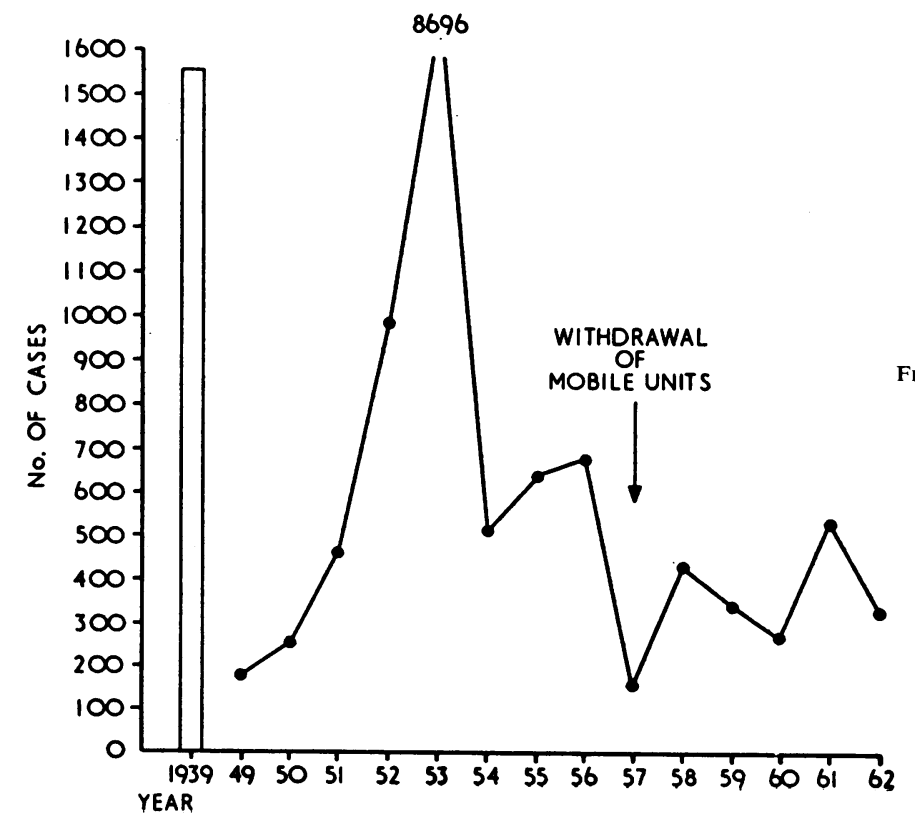

Preliminary Activities.-These had been fully discussed and approved at a meeting of medical officers (Health) and senior public health staff, 6 months before the start of the survey:

(1) The Health Education Unit would provide the necessary propaganda in each parish before the arrival of the team. For this purpose a special article was prepared by the consultant for publication in Jamaica Public Health.

(2) The M.O.H. would select suitable districts and clinics to which all persons who had been previously registered for a history or evidence of yaws, ulcers, and skin complaints, would be requested to assemble on a specified day.

(3) The VD/Yaws Officer would visit each parish to consult with the M.O.H. and his staff concerning the procedure to be adopted by the team, and the type of assistance that would be required, as set out hereunder:

(a) The district medical services in each parish would provide every possible assistance to the survey team.

(b) All active cases of yaws seen at the clinics would be treated by members of the district staff on recommendations by the yaws specialist or the consultant.

(c) The names of all infectious cases would be recorded at the time of inspection, and the local public health inspector would be responsible for rounding up contacts for treatment.

FIG. 3. - No. of cases recorded, 1949-62. 
(d) Appropriate treatment would be given to persons with non-specific ulcers and skin diseases on the day of their visit to the clinics.

(e) The consultant would be enabled to undertake special investigations during the survey.

Description of Work.-An itinerary of clinics was prepared by the Public Health Department of each parish, and relevant information relating to time and place of assembly, etc., was circularized and publicized. The programme of activities was arranged in such a way that during each week, 5 days were allocated to clinic sessions, and the sixth day was set aside for analysis of data and replenishment of stores.

The PAHO/WHO consultant assisted by a senior technician of the VD Division started work in each parish on a Monday morning. Work was started in the eastern section of Jamaica and continued so that parishes designated $\mathrm{A}$ to $\mathrm{L}$ in Table IV (see also Fig. 4) were studied in that order. The survey lasted 14 weeks, during which 4,600 miles were covered.

Equipment.-The team was provided with the following items:

(1) Penicillin (Penadur).

(2) Syringes and needles.

(3) Petroff needles and Wassermann tubes.

(4) One Smith McArthur field microscope.

(5) RPR card kits.

(6) Emergency equipment for treatment of reactions to penicillin.

(7) Sundry ointments to treat skin ailments.

Examination.-The name, age, sex, address, yaws history, and state on examination were recorded for every patient. The trunk, limbs, axillae, and when possible, the genital region of each patient were examined.
Diagnosis.-Patients with lesions presenting the classical features of yaws were diagnosed on clinical grounds.

Dark-field examinations were carried out in a limited number of cases. This procedure was restricted by the time element, and by the fact that most lesions had been treated with antiseptics.

Full advantage was taken of the speed of operation and simplicity of the RPR Card test. The following groups were selected on whom 3,107 tests were conducted:

(a) Patients with evidence of classical yaws.

(b) Patients with skin and other lesions simulating those of yaws.

(c) Patients with no clinical signs and no history of yaws.

(d) Patients giving a history of yaws, but with no evidence of disease.

Over 300 specimens of venous blood which had been submitted to the Card test, were collected for examination by other serological techniques for submission to the university and government laboratories. Two-thirds of each specimen were sent to the university for VDRL. The results of these examinations and of the 3,107 RPR Card test have already been reported elsewhere.

Treatment.- The schedule adopted, utilizing Penadur, is set out in Table III.

TABLE III

TREATMENT SCHEDULE

\begin{tabular}{l|c|c}
\hline \multicolumn{1}{c|}{ Classification } & Age Group (yrs) & Dose (ml.) \\
\hline Active Cases & Over 10 & $4(1,200,000$ units) \\
\hline Under 10 & 2 \\
\hline Contacts and Latent Cases & Over 10 \\
Under 10 & 2 \\
& & 1 \\
\hline
\end{tabular}

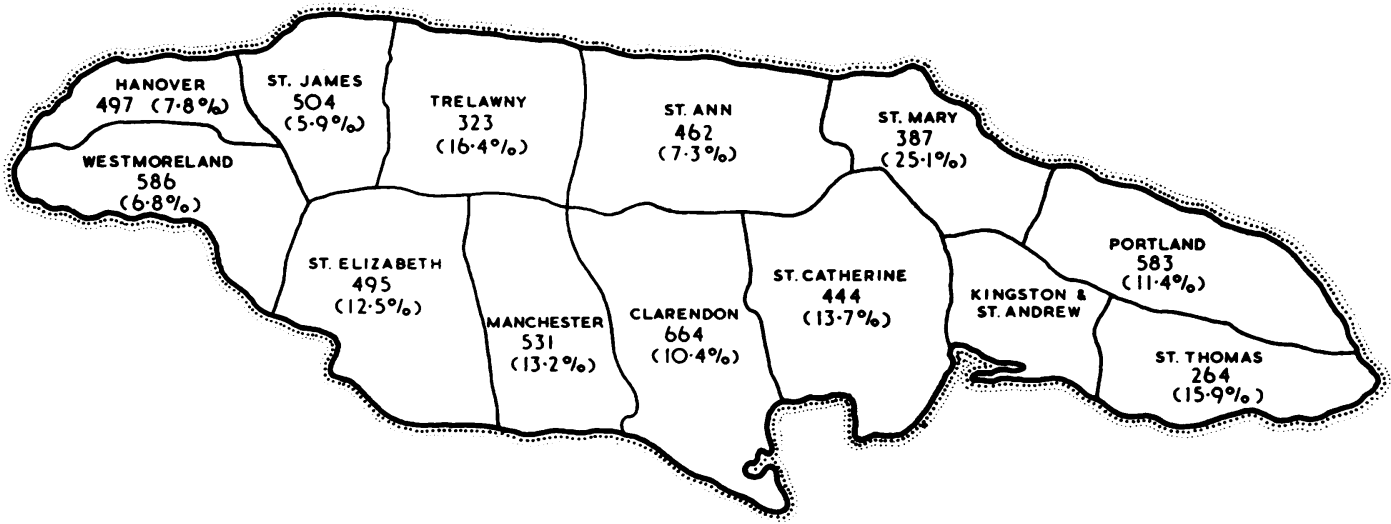

FIG. 4.-Patients examined and percentage found with yaws in twelve of the thirteen parishes of Jamaica. 
Patients with palmar and plantar hyperkeratosis, and those with late lesions were recommended to receive a total of 4 to 6 mega units in divided doses over a period of weeks. The administration of a minimum of $2 \mathrm{ml}$. to latent cases was recommended but was not always possible in this survey.

Data relating to the survey are presented in Fig. 4 and Table IV, and are summarized in Table V.

TABLE IV

YAWS SURVEY, JAMAICA, 1963

CASES IN EACH PARISH, BY STAGE AND AGE GROUP

\begin{tabular}{|c|c|c|c|c|c|c|c|c|c|c|c|c|c|c|}
\hline Stage & $\underset{(\mathrm{yrs})}{\text { Age Group }}$ & $\begin{array}{c}\text { A } \\
\text { St. } \\
\text { Thomas }\end{array}$ & $\begin{array}{c}\text { B } \\
\text { Port- } \\
\text { land }\end{array}$ & $\begin{array}{c}\text { C } \\
\text { St. } \\
\text { Mary }\end{array}$ & $\begin{array}{c}\text { D } \\
\text { St. } \\
\text { Ann }\end{array}$ & $\begin{array}{c}E \\
\text { Tre- } \\
\text { lawny }\end{array}$ & $\begin{array}{c}\text { F } \\
\text { St. } \\
\text { James }\end{array}$ & $\begin{array}{c}\text { G } \\
\text { Han- } \\
\text { over }\end{array}$ & $\begin{array}{l}\mathrm{H} \\
\text { West- } \\
\text { more- } \\
\text { land }\end{array}$ & $\begin{array}{c}\text { I } \\
\text { St. } \\
\text { Eliza- } \\
\text { beth }\end{array}$ & $\begin{array}{c}\mathrm{J} \\
\text { Man- } \\
\text { chester }\end{array}$ & $\begin{array}{c}\mathrm{K} \\
\begin{array}{c}\text { Claren- } \\
\text { don }\end{array} \\
\end{array}$ & $\begin{array}{c}\mathrm{L} \\
\text { Cathe- } \\
\text { rine }\end{array}$ & Total \\
\hline \multirow[t]{2}{*}{ Early } & $\begin{array}{r}0-4 \\
5-9 \\
10-14 \\
15-19\end{array}$ & $\begin{array}{l}1 \\
4 \\
7 \\
0\end{array}$ & $\begin{array}{r}3 \\
10 \\
10 \\
1\end{array}$ & $\begin{array}{r}6 \\
29 \\
18 \\
1\end{array}$ & $\begin{array}{l}2 \\
6 \\
6 \\
1\end{array}$ & $\begin{array}{r}0 \\
12 \\
4 \\
0\end{array}$ & $\begin{array}{l}2 \\
5 \\
3 \\
0\end{array}$ & $\begin{array}{l}1 \\
6 \\
5 \\
2\end{array}$ & $\begin{array}{l}3 \\
4 \\
4 \\
0\end{array}$ & $\begin{array}{l}44 \\
9 \\
7 \\
2\end{array}$ & $\begin{array}{l}1 \\
5 \\
5 \\
0\end{array}$ & $\begin{array}{l}1 \\
0 \\
6 \\
0\end{array}$ & $\begin{array}{r}1 \\
12 \\
10 \\
1\end{array}$ & $\begin{array}{r}25 \\
102 \\
85 \\
8\end{array}$ \\
\hline & Total & 12 & 24 & 54 & 15 & 16 & 10 & 14 & 11 & 22 & 11 & 7 & 24 & 220 \\
\hline \multirow[t]{2}{*}{ Late } & $\begin{array}{c}5-9 \\
10-14 \\
15-19 \\
20-24 \\
25+\end{array}$ & $\begin{array}{l}0 \\
2 \\
1 \\
0 \\
6\end{array}$ & $\begin{array}{r}0 \\
2 \\
1 \\
0 \\
20\end{array}$ & $\begin{array}{l}0 \\
1 \\
0 \\
0 \\
6\end{array}$ & $\begin{array}{l}1 \\
2 \\
3 \\
2 \\
4\end{array}$ & $\begin{array}{r}0 \\
4 \\
4 \\
0 \\
16\end{array}$ & $\begin{array}{l}0 \\
1 \\
0 \\
1 \\
5\end{array}$ & $\begin{array}{l}0 \\
3 \\
0 \\
0 \\
5\end{array}$ & $\begin{array}{l}0 \\
2 \\
0 \\
0 \\
6\end{array}$ & $\begin{array}{r}0 \\
1 \\
1 \\
1 \\
18\end{array}$ & $\begin{array}{r}0 \\
3 \\
2 \\
1 \\
29\end{array}$ & $\begin{array}{r}0 \\
0 \\
0 \\
2 \\
29\end{array}$ & $\begin{array}{r}0 \\
1 \\
0 \\
1 \\
21\end{array}$ & $\begin{array}{r}1 \\
22 \\
12 \\
8 \\
165\end{array}$ \\
\hline & Total & 9 & 23 & 7 & 12 & 24 & 7 & 8 & 8 & 21 & 35 & 31 & 23 & 208 \\
\hline Latent & $\begin{array}{c}0-4 \\
5-9 \\
10-14 \\
15-19 \\
10-14 \\
25+ \\
\text { Total }\end{array}$ & $\begin{array}{r}0 \\
4 \\
3 \\
1 \\
0 \\
5 \\
5 \\
13\end{array}$ & $\begin{array}{r}0 \\
2 \\
3 \\
1 \\
1 \\
6 \\
13\end{array}$ & $\begin{array}{r}0 \\
0 \\
2 \\
0 \\
0 \\
1 \\
13\end{array}$ & $\begin{array}{l}0 \\
0 \\
0 \\
0 \\
0 \\
0 \\
0\end{array}$ & $\begin{array}{l}0 \\
1 \\
1 \\
1 \\
1 \\
4 \\
8\end{array}$ & $\begin{array}{l}0 \\
2 \\
4 \\
0 \\
0 \\
1 \\
7\end{array}$ & $\begin{array}{r}1 \\
3 \\
5 \\
0 \\
0 \\
1 \\
10\end{array}$ & $\begin{array}{r}0 \\
4 \\
4 \\
1 \\
0 \\
3 \\
3 \\
12\end{array}$ & $\begin{array}{r}0 \\
2 \\
0 \\
0 \\
1 \\
10 \\
13\end{array}$ & $\begin{array}{r}0 \\
1 \\
0 \\
0 \\
1 \\
9 \\
11\end{array}$ & $\begin{array}{r}0 \\
1 \\
0 \\
1 \\
1 \\
10 \\
13\end{array}$ & $\begin{array}{l}0 \\
2 \\
1 \\
0 \\
0 \\
6 \\
9\end{array}$ & $\begin{array}{r}1 \\
32 \\
23 \\
5 \\
5 \\
56 \\
122\end{array}$ \\
\hline \multirow[t]{2}{*}{$\begin{array}{l}\text { Plantar } \\
\text { (Early } \\
\text { and Late) }\end{array}$} & $\begin{array}{c}0-4 \\
5-9 \\
10-14 \\
15-19 \\
20-24 \\
25+\end{array}$ & $\begin{array}{l}1 \\
2 \\
3 \\
1 \\
0 \\
1 \\
\end{array}$ & $\begin{array}{l}0 \\
1 \\
4 \\
1 \\
0 \\
1 \\
\end{array}$ & $\begin{array}{r}0 \\
6 \\
14 \\
1 \\
1 \\
1 \\
\end{array}$ & $\begin{array}{l}0 \\
1 \\
4 \\
2 \\
0 \\
0\end{array}$ & $\begin{array}{l}0 \\
0 \\
4 \\
0 \\
0 \\
1 \\
\end{array}$ & $\begin{array}{l}0 \\
3 \\
3 \\
0 \\
0 \\
0\end{array}$ & $\begin{array}{l}0 \\
0 \\
5 \\
0 \\
0 \\
2 \\
\end{array}$ & $\begin{array}{l}0 \\
2 \\
7 \\
0 \\
0 \\
0 \\
\end{array}$ & $\begin{array}{l}0 \\
2 \\
1 \\
1 \\
1 \\
1\end{array}$ & $\begin{array}{l}0 \\
0 \\
3 \\
1 \\
2 \\
7\end{array}$ & $\begin{array}{l}0 \\
3 \\
4 \\
0 \\
0 \\
9\end{array}$ & $\begin{array}{l}0 \\
2 \\
3 \\
1 \\
0 \\
8\end{array}$ & 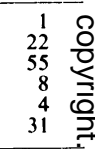 \\
\hline & Total & 8 & 7 & 23 & 7 & 5 & 6 & 7 & 9 & 6 & 13 & 16 & 14 & 121 \\
\hline Palmar & $25+$ & 一 & - & - & - & - & - & - & - & - & - & 2 & - & 2 \\
\hline \multicolumn{2}{|l|}{ Grand Total } & & & & & & & & & & & & & 673 \\
\hline
\end{tabular}

TABLE V

SUMMARY OF YAWS SURVEY, JAMAICA, 1963

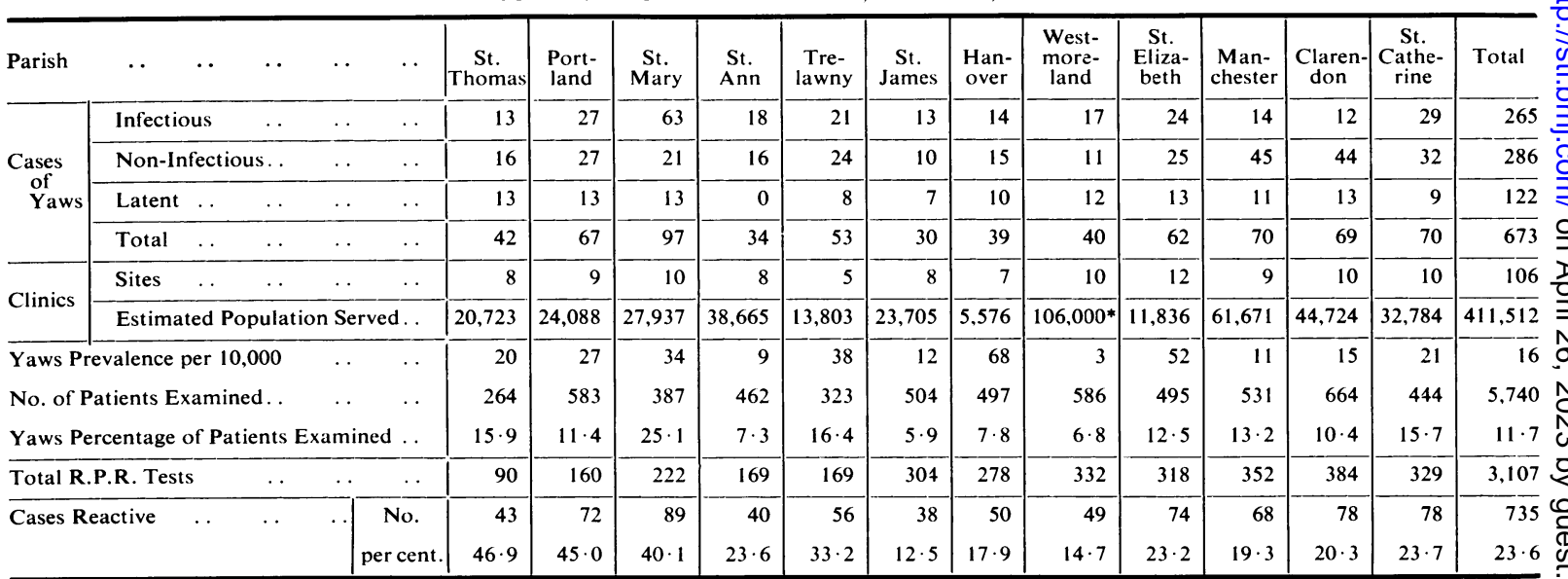

*1962 Estimated population.

Clinics held did not serve the number of people. 


\section{Discussion}

The work of the Jamaica Yaws Commission was primarily concerned with:

(a) The identification and extent of the problem.

(b) The epidemiological factors involved.

(c) Measures to be adopted for the control and final eradication of the disease.

In the 1933 issue of Jamaica Public Health, a member of the Commission stated that "The disease is prevalent, and probably many hundreds and even thousands of patients were in need of treatment in the parishes of St Thomas, Portland, St Mary, St Catherine, Clarendon, St Elizabeth, and St James. Data from the remaining six parishes were insufficient, but it was thought that there was also yaws in these parishes."

Subsequent work proved that yaws was prevalent in all the parishes of Jamaica, including that of Kingston and St Andrew. These findings were borne out by the Survey, except for the parish of St Andrew, which was not included because of the special inoculation programmes which were functioning there at that time.

A statement also appearing in Jamaica Public Health (1935) relating to the work of the Commission is worthy of quotation: "The first week in each area is given to the examination of patients, and an average of 7 weeks to treatment. A blood specimen is taken from each person at the first examination and again at the first treatment period. About 4 months after the completion of an area, the treatment team revisits the area for 2 weeks, to treat new cases and relapses. It is found that after a year by the use of the above plan, the incidence of yaws in the heaviest infected areas has been reduced to the point where it can be controlled by the district medical officers."

This assumption was made not only in Jamaica, but also in other parts of the Caribbean area, and further afield. When the prevalence of yaws in any area is reduced to a given quantity by selective measures, it is generally accepted that the DMO is adequately equipped to take over control. With very few isolated exceptions, this method has always failed to produce the desired results.

The only successful measures of control in areas where optimum conditions prevail for the maintenance and transfer of infection, are those aimed at eradication through treating total populations or selective groups by trained mobile teams. Once this has been accomplished, the district medical services can be called upon to take over surveillance, on the assumption that other public health activities, particularly those relating to environmental sanitation, will also be tackled. These methods have been very successful in many areas where yaws was once highly endemic, including five islands of the Eastern Caribbean, where this disease was a major public health problem within recent years.

A review of available statistical data for Jamaica shows that, when the mobile health units were in operation, there was a steady decline in the prevalence of yaws (see Fig. 3). In 1957, the units were withdrawn from service, but during the ensuing years it was evident that eradication had not been achieved. Nests of infection were recurring in some of the parishes, even though a team visited periodically to treat active cases. Results of the survey show that, in spite of these measures, infectious cases were still found in all twelve parishes.

Yaws can be eradicated quickly and effectively by the use of suitable methods adapted to prevailing circumstances. This objective is one that has been set for the Pan-American Sanitary Bureau by the governing bodies of the Pan-American Health Organization. Recommendations to this effect have been made, based upon the findings of the Survey.

\section{Summary}

The introduction of yaws into Jamaica followed the importation of African slaves during the 16th century. The disease was kept under reasonable control by the isolation of cases by estate owners in "yaws huts". After the emancipation, liberated persons dispersed throughout the country, and their faith in "Obeah" medicine coupled with their inability to pay for medical care resulted in the disease becoming widespread; 30 years of control effort by medical officers resulted in little or no reduction.

The Yaws Commission was organized in 1932 and functioned until 1937. Some very valuable work was published on the treatment, control, and epidemiology of this disease.

In 1938, control reverted to the local medical services, and four health units were maintained to cover the entire country. In 1955, the plan prepared for an International Programme for the Eradication of Yaws and Control of Venereal Diseases was not undertaken for financial reasons. During the ensuing 4-year period, the health units succeeded in bringing about a marked reduction in cases. It was considered that, for all practical purposes, eradication had been achieved, and, as a result, surveillance activities were relegated to the District Medical Services.

In 1963, a Survey was organized by the Ministry of Health, with the assistance and advice of the WHO/PAHO VD/T consultant for this zone, to 
determine the extent and characteristics of the problem. Over a period of 3 months, all but one of thirteen parishes were covered by a series of clinics held at selected centres. The results of the Survey are summarized in Table V.

Past experience with campaigns designed to control and eradicate yaws has shown that these objectives are attained only when proven methods are adopted.

The author acknowledges assistance received from the Ministry of Health, Kingston, Jamaica, Dr E. Sutherland (VD/Yaws Officer), and Mr B. A. P. Kerr (Team Member from the VD Division). Reference has been made to the Handbook of Jamaica (1962), the Annual Reports of the Jamaica Yaws Commission, the Jamaica Public Health Reports, and the records of the Pan-American Health Organization.

\section{Études sur le Pian en Jamaïque 1963 \\ RÉSUMÉ}

Le pian fut introduit en Jamaïque par l'importation d'esclaves africains pendant le 16ème siècle. La maladie se maintint à un niveau raisonnable, grâce à l'isolement des cas par les grands propriétaires, dans des "huttes à Pian". Après l'émancipation, ces malades libérés se dispersèrent à travers le pays et leur foi en la médecine "obeah" associée à leur incapacité de payer les soins médicaux résultèrent en la dissémination de la maladie; 30 années d'efforts de la part des médecins donnèrent peu ou pas de résultats.

La commission pour le Pian fut organisée en 1932 et fonctionna jusqu'en 1937. Un travail très valable fut publié sur le traitement, le contrôle et l'épidémiologie de cette maladie.

En 1938 le contrôle de la maladie fut confié aux services médicaux locaux, et quatre unités de santé furent maintenues pour le pays entier. En 1955 le projet de programme international pour la suppression du Pian et le contrôle des maladies vénériennes ne fut pas entrepris pour des raisons financières. Pendant les 4 ans qui suivirent, les unités de santé réussirent à obtenir une diminution notoire des cas de Pian. On considéra qu'en pratique la maladie avait été supprimée, et de ce fait sa surveillance fut confiée aux services médicaux du District. En 1963, une étude fut organisée par le Ministère de santé avec l'aide et les avis du médecin consultant du WHO/ PAHO VD/T de cette région, pour établir l'étendue et les caractéristiques du problème. Pendant une période de 3 mois les treize paroisses, sauf une, furent couvertes par une série de dispensaires établis dans des centres choisis.

Les résultats de cette étude sont résumés dans le tableau V.

L'expérience passée des campagnes de contrôle et de suppression du Pian a montré que ces objectifs sont seulement atteints quand des méthodes de traitement éprouvées sont adoptées. 